belong? Unpublished lecture, University College London.

1985. The past is a foreign country. Cambridge: Cambridge University Press.

1987. Where does our architectural heritage belong?, in Old cultures in new worlds (Proceedings of the ICOMOS 8th General Assembly]: 685-92. Washington (DC): International Council on Monuments and Sites.

LUKE, Y. 1987. The shock of the old: reactions to the Parthenon marbles during the 19th century. Unpublished paper, seminar on Uses of the Past, University College London.

McBryde, I. (ed.). 1985. Who owns the past? Melbourne: Oxford University Press.

MCNLILL, W.H. 1978. The metamorphosis of Greece since World War II. Oxford: Basil Blackwell.

Pevsner, N. 1952. The buildings of England: London 2: except the cities of London and Westminster. Harmondsworth: Penguin.

Richards, O. 1982. A fairer Athens \& a freer Rome: historic public gardens in Perth, W.A., Heritage Australia 1(1): 66-9.

RuSkIN, J. 1886. Modern painters. New York: John Wiley. ST ClaIR, W. 1972. That Greece might still be free: the philhellenes in the War of Independence. London: Oxford University Press.
SCully, V. 1962. The earth, the temple and the gods. New Haven: Yale University Press.

SHELLEY, P.B. 1821. Preface to 'Hellas', in Shelley [1934]: The complete poetical works: 447. London: Oxford University Press.

SymoNDS, J.A. 1874. Sketches in Italy and Greece. London: Smith, Elder.

Tsigakou, F.-M. 1981. The rediscovery of Greece: travellers and painters of the romantic era. London: Thames \& Hudson.

TuRnER, F.M. 1981. The Greek heritage in Victorian Britain. New Haven: Yale University Press.

WEBSTER, D. 1824. The revolution in Greece, in Webster [1903]: The writings and speeches of Daniel Webster: 5: 60-95. Boston: Little, Brown.

Williams, S.A. 1984. Recent developments in restitution and return of cultural property, International Journal of Museum Management and Curatorship 3: 117-29.

WINCKELMANN, I.J. 1755. On the imitation of the painting and sculpture of the Greeks, in Irwin (1972): 61-85. 1764. History of ancient art, in Irwin (1972): 104-44.

Woolf, V. [1987.] A dialogue upon Mount Pentelicus, Times Literary Supplement 11-17 September: 979.

WorDsworth, C. 1839. Greece: pictorial, descriptive, historical. London: William S. Orr.

\title{
Expressions of wealth: Greek art and society
}

\section{DAVID W.J. GILL*}

In the 2nd century AD Pausanias (i.2.4-15.1) walked through the agora at Athens describing some of the statues and naming the artists; at least 35 of the statues were of bronze, yet not a single one survives intact today (Mattusch 1982: 8-9). Thinking only of the extant marble sculpture does an injustice to the civic art of Athens. This problem is commonplace; almost any classical site has numerous stone bases for bronze statues which have long gone into the melting-pot. Yet so often in modern scholarship stone sculpture is given a privileged position. Although modern histories of Greek art pay much attention to the marble sculpture of the Parthenon, ancient authorities were not so impressed; Pausanias (i.24.5-7) provides the briefest of descriptions to the marble sculpted pediments and omits to mention the frieze. For many scholars today the frieze has become an example of what 'unlimited money can do' (Ashmole 1972: 116), yet, as R. Osborne has recently pointed out, it merely helped the viewer to process to the east end of the temple where he or she would have been confronted by the great chryselephantine cult-statue of Athena: 'this is what the temple was built to

* Fitzwilliam Museum, Cambridge св2 1RB.

ANTIQUITY 62 (1988): 735-43 
display, this is the object towards which worship is directed, and this is what the procession was all about' (Osborne 1987: 101). And this is what Pausanias describes in detail, the great work of art and expression of Athens' wealth which no longer survives.

Classical archaeology grew out of 'connoisseurship', that is, of the informed study and collection of classical antiquities (Vickers 1985c; 1987; cf. Snodgrass 1985a; 1987: 1-35). As it is only possible to collect what exists, classical archaeology became particularly concerned with stone sculpture and painted pottery. In addition a special attitude has informed classical archaeology for - ever since the Romans modelled their architecture on Greek, and removed or copied Greek sculpture to decorate their own buildings (e.g. Vermeule 1977) - Greek art has been revered and respected not as just another style of ancient art but as an absolute ideal. However, in the Roman era, in the Renaissance, in 18th- and 19thcentury neo-classicism, and most recently in the new classical revival of post-modern architecture, it is Greek models which have been followed as the great masterpieces. This veneration - over 20 centuries old now - for classical models has brought together and confused two distinct issues: first, the place of these objects in the modern world, and, second, the place of these same objects in the ancient world. Thus it does not follow that because the Parthenon marbles are regarded today as among the greatest artistic achievements of all times or all places, that they held the same status in 5thcentury Athens. There is also a danger that if we only study and collect those things that do survive, then we will respect only those elements that have survived whether or not they were, in their own time, respected as great art, or left unregarded as unimportant.

Fortunately we do not need to be ensnared by

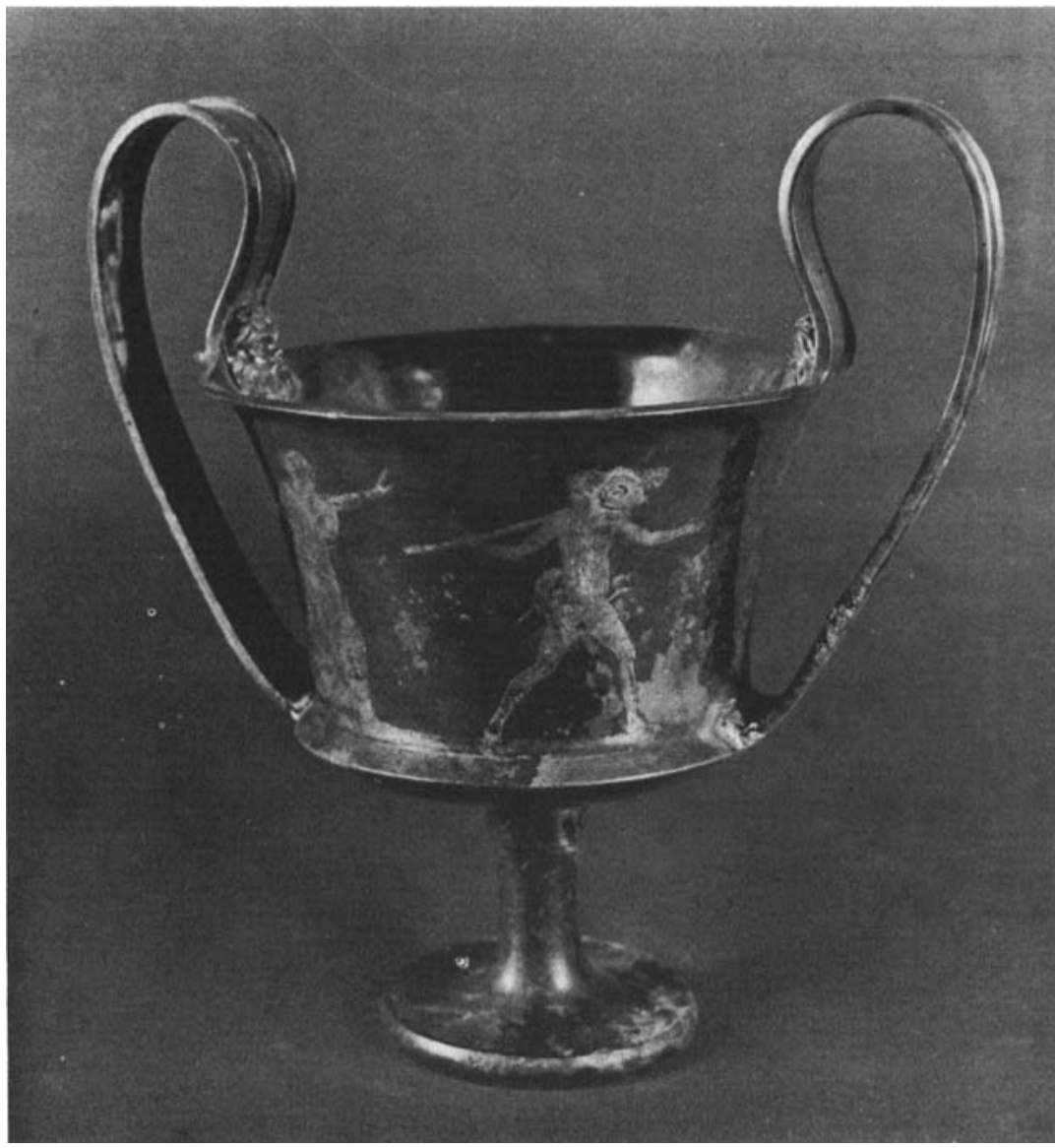

FIGURE 1. Silver

kantharos with goldfigure decoration from Duvanli in Bulgaria (Plovdiv, Archaeological Museum). 
these centuries of classical reverence. The standard methods of field archaeology - by survey, excavation and post-excavation study give a direct kind of evidence which may be weighed against contemporary literary and epigraphic texts which have much to say about the material culture, and give their own opinions of what was precious and why. No longer when we deal with the classical world need we feel 'restricted to a consideration of what has survived' (Kurtz \& Boardman 1971: 203), especially as this might lead us to disregard the substantial body of documentary evidence and cause us to be 'guilty of an impoverishment of the past' (Vickers 1985/6: 155). Archaeologists of other periods and cultures are well aware of these problems. Thus C.R. Dodwell in his reevaluation of Anglo-Saxon art has suggested that 'if the survival pattern of the various crafts of the Anglo-Saxons has distorted our knowledge of their arts, it has also falsified our understanding of their tastes' (Dodwell 1982: 12). How then does classical art look in the light of what classical authors themselves tell us of their society?

Most classical archaeologists use fine painted pottery as an index of wealth: pots found in the tomb represent the high status of the person buried there. This notion goes back at least as far as George Dennis's Cities and cemeteries of Etruria, first published in 1848 , which states: 'there can be little doubt, whatever purpose they originally served, that these vases were placed in the tomb by the ashes of the deceased, together with his armour and jewellery, as being among the articles which he most prized in life' (Dennis 1848: lxxxiii).

J.D. Beazley, writing a century later about the contents of a tomb at Capua, took a similar attitude. Of two pots which seemed to be older than the others in the tomb, he remarked, '[they] must have been treasured for many years before they were placed in the grave. Treasured it may be by more than one owner - father and son, father and daughter's husband. Treasured as wonders, not of minor art or industrial art (in the shoddy jargon of today or yesterday), but of art pure and simple: not panchrusa . . . but peak of possessions, korupha kteanon' (Beazley 1945: 158). The classical allusion is to Pindar's Seventh Olympian Ode; but there it describes not a pot of dubious value in antiquity but rather a gold cup. Beazley in this case was clearly not in tune with values in antiquity, despite his 'profound understanding of the classical languages' (Boardman 1987: 295), and recent attempts to make him seem less uninformed are probably somewhat misdirected (Cook 1987: $170)$.

These views about pots from the tomb are routine today: 'the ancient Etruscans collected Greek pottery (though not systematically) which they prized highly, imitated, and buried with their dead' (Moon 1979: xvii; cf. Vickers 1985/6: 165); in Campania and Apulia 'chamber-tombs yielded quantities of vases which were held in high esteem primarily because of the subjects represented on them' (Trendall 1982: 15).

Are tombs containing decorated pots the burials of people with high status? Even with the large numbers of 5 th-century BC burials often accompanied by painted pots - known at Athens (some 1800 graves), it has been calculated that this only represents about $1.7 \%$ of the resident population (Morris 1987: 100). Thus we need to recognize that some social classes might be invisible in the archaeological record. I. Morris has drawn a parallel with Bali where 'until recently the highest-ranked individuals were exposed without any subterranean disposal facilities', which would leave the result that 'only the poorest members of society would be visible to the archaeologist' (Morris 1987:93-4).

Cremation may have been favoured by the upper-classes in 5th-century BC Athens (Vickers 1984: 94-5). During the plague at Athens in $430 \mathrm{BC}$ this practice seems to have been abused by social groups who would probably under normal circumstances have practised inhumation: 'they would arrive first at a funeral pyre that had been made by others, put their own dead upon it and set it alight; or, finding another pyre burning, they would throw the corpse that they were carrying on top of the other one and go away' (Thucydides ii.52.4; cf. Vickers 1984: 95). Laws against the use of olive wood 'for the disposal of a corpse' ([Demosthenes] xliii.71) are perhaps part of a wider move against using cremation as a display of wealth. In Greek society those who would have cremated their dead are unlikely to have lived on a ceramic standard. A good example is the so-called Royal Tomb at Vergina where ivory objects seem to have been placed on the funeral pyre; the cremated remains were placed in a 
gold box and funerary goods included a quantity of silver plate. Indeed descriptions of wealthy funerals fail to mention decorated pots but include items made of gold, silver, ivory and other expensive media (Vickers 1984: 94).

It should also be remembered that wealth was rarely disposed of in the grave (Childe 1944: 86). A.M. Snodgrass has noted that during the Geometric period as the number of bronze objects buried in tombs decreased, the number of similar artefacts dedicated in sanctuaries increased (Snodgrass 1980: 52-4). I. Morris has developed this idea and shown that although the mean number of metal artefacts per intact adult burial at Athens falls from 1.7 during the Submycenaean period to 0.8 in the Late Geometric (with a high of 2.8 in the Early and Middle Geometric periods), the number of pots over the same chronological span increases from 1.3 to 6.8 (Morris 1987: 141 table 9, 142 figure 48). In addition $H$. Hoffmann has proposed that pots in a funerary context may be no more than 'tokens and symbols' substituted for the real wealth especially gold and silver plate -which was 'passed down the generations for heirs to inherit' (Hoffmann 1988: 152).

From burials let us turn to settlements. It has long been assumed that possession of fine pottery, especially Corinthian or Attic, was a sign of wealth in life, as it had been assumed to be in death. As a recent American exhibition catalogue of Greek vase-painting puts it, 'vases have been collected by kings and emperors, lords and ladies, scholars and poets, and business people from America, Europe and the Far East' (Moon 1979: xvii). Another, of the Nelson Bunker Hunt and William Herbert Hunt Collections of pots and bronzes (among other items), is entitled Wealth of the ancient world (Tompkins 1983). R.M. Cook, in a section on 'prosperity' in his Greek painted pottery, declares: 'it is likely enough that at any one time the Greeks were uniform in their uses, domestic and dedicatory, of painted pottery. So it should be possible to compare the prosperity of contemporary settlements and sanctuaries by the amount and quality of the pottery found in them, if the finds are representative' (Cook 1960: 278).

These views are common enough in the excavation reports of houses and farmhouses. At Athens, for example, 'even the modest dwellings on the Areopagos slope were occupied by men of moderate means, to judge by their contents, which included fine pottery' (Thompson \& Wycherley 1972: 182); and a well-fill of a house to the south-west of the agora included fine pottery which shows that the occupants of this modest house were not so poor as one might expect' (Thompson \& Wycherley 1972: 174). In the countryside of Attica, the excavators of the Dema House suggested that the fictile tableware - which included an Attic red-figured bell-krater - was relevant to 'a typical prosperous Athenian family' (Jones et al. 1962: 100; cf. Osborne 1985: 190). However these buildings are not even likely to be complete or provide representative samples of a household's possessions, for - as well as the normal archaeological vagaries of survival and recovery - there is evidence of material being removed from domestic sites. At the Dema House most of the tiles had been taken away, and the 'small finds were scanty, and hardly representative of all the furnishings and possessions one might expect in a house of so considerable a size' (Jones et al. 1962: 83, $101 \mathrm{n}$. 26). This dismantling of structures is found at both rural (e.g. Jones et al. 1973: 360) and urban (e.g. Young 1951: 195) sites. Greek homes are often thought of as being rather bare places (e.g. Pritchett 1956: 212; Wycherley 1978: 245) yet the lists of confiscated property from the mutilators of the herms at Athens showed that some of the homes were decorated with a range of furnishings which included pinakes, probably pictures on wooden boards (Pritchett 1956: 250-3).

These problems are of particular importance to field-survey. If we find the surface remains of structures from which most things of any value have been stripped, then how are we to interpret the remains? Indeed if the very poor could not afford pottery (and there is evidence for the use of wooden vessels in the countryside (e.g. Athenaeus xi.495.a)), this group will be virtually invisible in the archaeological record that reveals itself in surface-survey. At the other social extreme, a wealthy class using gold, silver or bronze instead of pottery would again not be so visible archaeologically. The ceramic record of surface-survey would be a sample dominated by the middle of the social classes, rich enough to have pots, poor enough not to have better. Indeed, the presence of tile and other architectural traces without fine pottery might suggest to some a non-residential site 
whereas the extant surface record might not be as straightforward to interpret. By this same process, the periods noted for a low level of ceramic imports may actually reflect times of greater prosperity. M.G. Fulford says of the finds at Carthage: 'Presumably during periods of relatively low ceramic imports of all kinds the social élite had chosen to acquire luxuries which do not register so conspicuously in the archaeological record. Metalware and glass for example, might have been more prevalent than table-ware pottery' (Fulford 1983: 12). The reluctance of Scythians to be impressed by Greek painted vases' (Boardman 1980: 259) may be because they were receiving payment for their grain in precious metal (Gill 1987a: 50-1). Before leaving field-surveys it might be worth pointing out that periods of high site density, characterized by an increase in the amount of imported fine wares (e.g. Candarli, African Red Slip and Phocaean) in the Middle and Late Roman periods in Greece may not be a sign of prosperity but rather of high taxation - partly in kind - which would encourage increased exploitation of the landscape and export of staples (Mee et al., in press).

The appearance of fine decorated pottery at a site is neither a simple indicator of wealth (as the old orthodoxy suggests) nor a simple indicator of the middle of the social classes. It is being more widely recognized among classical archaeologists that the movement of pottery by sea was a by-product of trade in staples and other important commodities (cf. Boardman 1987: 293; 1988: 27). Shipwrecks suggest that maritime trade often included the long-distance movement of commodities that are of no great value in themselves but worth transporting if more valuable things had to travel in the same, or even opposite, direction. Thus the archaeological evidence would suggest that small consignments of pottery were carried amidst the main cargo as a 'saleable ballast' (Gill 1987b; $1987 \mathrm{C} ; 1988 \mathrm{a} ; 1988 \mathrm{C}$; in press).

A.J. Parker's (1984) analysis of cargoes has shown that pottery, other than transport amphorae, "may not account for more than about 20 per cent of the recovered cargoes' (Fulford 1987: 61). At the same time it should be remembered that pottery due to its durable nature is easy to detect in difficult water conditions and is thus likely to figure much more prominently in what is recovered from the seabed than in what sank down to it 2000 and more years ago. Pottery production may also have been stimulated by vigorous trade. M.G. Fulford (1987: 69), looking at pottery production in this wider context of Mediterranean trade, observes:

given that the demand for surplus foodstuffs was broad-based, the best way of ensuring a widespread distribution of manufactured goods, such as pottery, was to ship them alongside foodstuffs. It is then perhaps not surprising to find the major potteries within traditionally fertile regions with access (by sea) to wide markets. In the case of Italy the most important sources of pottery - Etruria (Arretine, wine amphorae), Campania (black-glazed ware, cooking wares and wine amphorae) correspond with the most important agricultural regions, renowned for the quality and yields of their cereals.

If we take the example of pottery production at Athens, its export could equally be secondary to, among other things, the shipping of silver from the Laurion mines of Attica. Indeed Attic pots have been found alongside a consignment of silver (and lead) on the Porticello shipwreck (Eiseman 1979; 1980). It is important to remember that trade was two-way. An area like Etruria may have been receiving Greek pots, not because the Etruscans 'were apparently enthusiastic students of Greek mythology' (Shapiro 1981: 10), but because it mirrored the export of iron (Gill 1987b), and, as Critias (ap. Athenaeus i.28.b-c; but cf. Boardman 1987: 294) reminds us, Etruscan gold phialai and bronzeware to Athens in the 5th century BC.

The actual value of pots as a commodity in maritime trade may be provided by a series of commercial graffiti scratched on the underside of several Attic red-figure bell-kraters; these include lists of different pots with their prices (Amyx 1958: 289-92; Johnston 1979: Type 14F, nos. 1-5). Their value per set of large and small pots, ranging between 58 and 96 pots per set, was approximately 5.5 drachmae. If we use one of the lowest known figures for the price of wheat, 5 drachmae per medimnos (Pritchett 1956: $196-8 ; 1$ medimnos $=52.53 \mathrm{l}$ ), the value of a shipment of 3000 medimnoi of wheat would be the equivalent of c. 3000 sets or around a quarter of a million pots. One of the higher prices of 9 drachmae per medimnos for wheat would have required the equivalent of half a million pots. If we compare the values per 
cubic metre, wheat at 5 drachmae per medimnos is worth 95 drachmae whereas the sets of pots (including the six bell-kraters) were only worth 42 drachmae. These exchange rates between painted pots and bulk cereals do not sit happily with a view of painted pottery as a high, fine and valuable art. Indeed there seems to be little support for J. Boardman's claim that pottery was 'as valuable and profitable a trade commodity as most that any classical ship took on board' (Boardman 1988: 33; and cf. Gill $1988 \mathrm{C})$.

Those who study painted pottery rarely point out that the highest recorded price for a figuredecorated pot was 3 drachmae. Prices for other decorated pots are considerably lower, for instance 4 obols for a red-figured krater, and a mere 7 obols for a belly-amphora (Type A) by the 'Berlin Painter' ( 6 obols $=1$ drachma). These low prices have often troubled scholars. H.B. Walters, in his History of ancient pottery (1905), said: 'no positive mention [of price] occurs in classical authorities, yet it is most probable that vases of the best class, the products of eminent painters, obtained considerable prices' (Walters 1905: 43). Evidence for this opinion came not from a classical source, but in the prices for these pots in recent sales where they realized 'considerable sums' (Walters 1905: 43; cf. Reitlinger 1963: 369-73). The idea of there being an ancient fine-art market in pots has been widespread (e.g. Richter 1904-5; 237-8) and is still with us today (cf. Gill, in press).

The high view of the status of pottery in antiquity needs to be seen against the background of the Near East. It was an area where gold and silver plate was in widespread use (e.g. Moorey 1980) and, at least in the Achaemenid Empire, so Ctesias (late 5th century BC) tells us, pottery despised: 'among the Persians any man who falls under the king's displeasure uses clay drinking-cups (kerameois poteriois)' (ap. Athenaeus xi.464.a). The exotic nature of this eastern plate has rightly been recognized as an important influence on new Attic pottery forms in the early decades of the 5 th century BC (e.g. Hoffmann 1961; Shefton 1971). It was to this model which the social élites of the Greek world aspired, but as so little plate - in contrast to painted pottery - has survived from the Greek world, a thesis has been proposed that the upper classes of the tiny poleis could not afford the pomp of Assyria and Persian monarchs; instead of gold and silver vessels Greek aristocrats had to make do with elaborately painted vases' (Starr 1982: 440).

This association between decorated pottery and people of high social ranking has allowed a pot such as the Attic black-figured krater, better known as the François vase, to be linked with 'one of the premier aristocratic families' in Etruria (Stewart 1983: 69). Many present-day scholars assume pottery to have been a luxury, if only because of the craftsmanship of the work. Warren G. Moon (1979: xix) provides an example:

The Greeks often took something basic, like pottery, and raised it to new aesthetic heights. Greece was poor in metals but especially rich in clay ... Luxury vessels, that is, vases which are more special than kitchen ware, were often made by other ancient peoples in gold, silver and bronze. Sometimes the Greeks imported these precious items; occasionally the Greeks made their own metal vases. But in Athens and elsewhere pottery itself was made extraordinary

This in turn led to an ideal view of Greek society where pottery was held in high esteem (Raby \& Vickers 1986), and plate confined to sanctuaries (e.g. Strong 1966: 74) and 'barbarian' societies which either had poor taste or did not know any better. This position is one held by D.E. Strong, author of the standard work on Greek and Roman gold and silver plate (Strong 1966), who was apparently not aware of the widespread use of plate in the Greek world. In a discussion of a Lycian silver head-vase (Strong 1964: 99) he suggested that it was an example of the Greeks

making expensive metal versions of clay vases for the barbarians on the fringes of the Greek world, even when fear of hubris prevented their use in Greece, and when this vase was made domestic silver was coming into general use and most clay shapes had their counterparts in silver and gold. It may, therefore, be nothing more than an expensive domestic vessel, for show perhaps rather than use.

Such is the confusion over the status of painted pottery that the argument has come a full circle and Athenian pottery found at Al Mina at the mouth of the Orontes could be interpreted as imports 'for the use of the Persian court circles which would naturally demand the best' (Woolley 1953: 175). 
M. Vickers $(1983 ; 1984 ; 1985 a ; 1986$; Vickers et al. 1986) in contrast has reminded us of the enormous wealth of evidence for the use of gold and silver plate in antiquity of which so little has survived. Plate, unlike pottery, has an intrinsic value - and it thus matters little if 'there is some very shoddy work in gold and silver, and most known or recorded specimens are undecorated or very simply decorated' (Boardman 1987: 293) - and thus can be reworked; booty, theft and the ravages of time have deprived us of this important aspect of evidence. The endless temple inventories from Athens, Delos and elsewhere are forceful reminders of this important aspect of ancient wealth (Lewis 1986). Those who oppose this view have suggested that it is surprising that none or few of these fine objects have been found (Boardman 1987: 286, 288), yet it is clear that the survival rate for plate is not good. For the hundreds of items of plate attested in epigraphic and literary texts for Athens, I know of only two extant items, both of the Hellenistic period (London: Walters 1921: 22, plate xiii, no. 80; New York 16.62: von Bothmer 1984: 48 no. 80). One of the few pieces of evidence raised in support of pottery having high status in antiquity is that of monumental pots which were used to mark graves in the Geometric period (Robertson 1985: 24); but, of course, that is no evidence that pots were used in the homes of the rich, especially in later periods. Beazleyism (cf. Sherratt 1987: 320 - rather than Beazley - has done classical archaeology a great disservice by discussing pots as items of value, cherished by 'connoisseurs' (Boardman 1974: 7; 1975:7) both ancient and modern. There is little wonder that M. Robertson (forthcoming) is concerned that 'one effect of Beazley's classification, and of the fascination of playing the attribution game, is that the whole of vase-painting has been lifted into a position of importance in ancient arthistory beyond its deserts'. If I may paraphrase a recent review by Andrew Sherratt (1987), 'it would be a pity if our ideas about Greek society were no more original than to create "The Painter of the Woolly Satyrs"”.

Reconstructing society can not be removed from chronology. It is clear that recent challenges to the widely-held framework (e.g. Francis \& Vickers 1981; 1983; 1988; Vickers 1985b; Gill 1988b) have reminded us that different interpretations are possible with the existing evidence (Snodgrass 1985b: 199). One important result of the revisions may be to move some art to the prosperous years after the Persian Wars. We may recall Diodorus' (xii.3-4) testimony that after the Persian Wars

every Greek city was filled with such abundance that everyone was amazed at the change for the better. For the next fifty years Greece enjoyed great progress towards prosperity. During this time the crafts increased owing to prosperity, and the greatest artists are mentioned as having flourished at this time ... .

Such prosperity is consistent with the outline for the economic growth of the Mediterranean basin proposed by K. Hopkins (1983: xiv-xxi; cf. Vickers 1985b: 32-3) for the last millennium BC and the first two centuries AD.

The abundance of texts relating to the Greek world provides us with a glimpse of the wealth of antiquity. Luxury items, which are absent in the archaeological record but present in the epigraphic and documentary sources, require us to reassess the way that we interpret the extant material culture. If a consistent picture is to be derived from the archaeological and documentary evidence we might conclude that vessels of gold and silver rated higher than painted pots, which in turn had their own social standing and place in burial ritual - a place whose standing is vividly stated by the cheapness of pots in cash terms. Accordingly, the trade in painted pottery was not the purpose of long-distance exchange, but a convenient secondary exchange to accompany the more valuable commodities of oil, grain, wine, metals and slaves. In their own time these were painted pots and it is only the connoisseurs of our own time who have chosen to call them by the grander title of 'vases'. Vases they may be to us, but that name and its associations do not inform us about ancient Greece.

A picture of ancient Greek artefacts is emerging which is less idealized than the 19thcentury view. It was a society which cared much more for gold, silver and obviously precious things than for painted pots, for ivory or metal sculpture rather than for stone - a society, in short, which is very much more like the picture derived from the texts rather than the imagined world, of timeless philosophers and aesthetes, that underpins the practice of classical archaeology as connoisseurship. 
Acknowledgements. I am grateful to Hugh Bowden, Michael Fulford, Christopher Mee, Andrew Sherratt, Anthony Snodgrass, A.J.S. Spawforth, Timothy Taylor, and Michael Vickers for their comments and advice. Much of the work is derived from my research in the Department of Classics, University of Newcastle upon Tyne during the tenure of a Sir James Knott Fellowship and I would like to thank my former

\section{References}

AMyX, D.A. 1958. The Attic Stelai, III: vases and other containers, Hesperia 27: 163-310.

Ashmole, B. 1972. Architect and sculptor in Classical Greece. New York: New York University Press.

BEAZLEY, J.D. 1945. The Brygos Tomb at Capua, Americon Journal of Archaeology 49: 153-8.

BOARDMAN, J. 1974. Athenian black figure vases. London: Thames \& Hudson.

1975. Athenian red figure vases, the Archaic period. London: Thames \& Hudson.

1980. The Greeks overseas: their early colonies and trade. London: Thames \& Hudson.

1987. Silver is white, Revue Archéologique 279-95.

1988. Trade in Greek decorated pottery, Oxford Journal of Archaeology 7: 27-33.

vON BOThMER, D. 1984. A Greek and Roman Treasury, Bulletin of the Metropolitan Museum of Art 42,1 Summer.

ChILDE, V.G. 1944. Progress and archaeology. London.

COOK, R.M. 1960. Greek painted pottery. London: Methuen.

1987. 'Artful crafts': a commentary, Journal of Hellenic Studies 107: 169-71.

Dennis, G. 1848. Cities and cemeteries of Etruria. London: John Murray.

DODWELL, C.R. 1982. Anglo-Saxon art, a new perspective. Manchester: Manchester University Press.

Eiseman, C.J. 1979. The Porticello shipwreck: lead isotope data, International Journal of Nautical Archaeology 8: 339-40.

1980. Greek lead: ingots from a shipwreck raise questions about metal trade in Classical times, Expedition 22,2: 41-7.

Francis, E.D. \& M. VICKERS. 1981. Leagros kalos, Proceedings of the Cambridge Philological Society 207: 96-136.

1983. Signa priscae artis: Eretria and Siphnos, Journal of Hellenic Studies 103: 49-67.

1988. The Agora revisited: Athenian chronology $c$. 500-458 BC, Annual of the British School at Athens 83.

Fulford, M.G. 1983. Pottery and the economy of Carthage and its hinterland, Opus 2: 5-14.

1987. Economic interdependence among urban communities of the Roman Mediterranean, World Archaeology 19: 58-75.

GiLl, D.W.J. 1987a. Two new silver shapes from Semibratny, Annual of the British School at Athens 82: 47-53.

1987b. METRU.MENECE: an Etruscan painted inscription on a mid-fifth century BC red-figure cup from Populonia, Antiquity 61: 82-7.

1987c. The date of the Porticello shipwreck: some colleagues (and students) for their encouragement. The support and assistance of the Director and Syndics of the Fitzwilliam Museum is gratefully acknowledged. An earlier version of this paper was given at the symposium 'Europe in the First and Last Millennia, Social Reconstruction 1000 BC-AD 1000,' Oxford, March 1988.

observations on the Attic bolsals, International Journal of Nautical Archaeology 16: 31-3.

1988a. Silver anchors and cargoes of oil: some observations on Phoenician trade in the western Mediterranean, Papers of the British School at Rome 56.

$1988 \mathrm{~b}$. The temple of Aphaia on Aegina: the date of the reconstruction, Annual of the British School at Athens 83: 169-77.

1988c. 'Trade in Greek decorated pottery': some corrections, Oxford Journal of Archaeology 7: 369-70.

Forthcoming. The distribution of Greek vases and long distance trade, in Proceedings of the 3rd International Symposium on Ancient Greek and related pottery, Copenhagen 1987.

Hofrmann, H. 1961. The Persian origin of the Attic rhyta, Antike Kunst 4: 21-6.

1988. Why did the Greeks need imagery?: an anthropological approach to the study of Greek vase painting, Hephaistos 9: 143-62.

Hopkins, K. 1983. Introduction, in P. Garnsey, K. Hopkins, \& C.R. Whittaker (ed.), Trade in the ancient economy: ix-xxv. London: Chatto \& Windus.

Johnston, A.W. 1979. Trademarks on Greek vases. Warminster: Aris \& Phillips.

Jones, J.E., A.J. GRahaM, \& L.H. Sackett. 1973. An Attic country house below the cave of Pan at Vari, Annual of the British School at Athens 68: 355-452.

JonEs, J.E., L.H. SACKETT \& A.J. Graham. 1962. The Dema House in Attica, Annual of the British School at Athens 57: 75-114.

Kurtz, D.C. \& J. BOARDMAN. 1971. Greek burial customs. London: Thames \& Hudson.

LEWIS, D.M. 1986. Temple inventories in Ancient Greece, in Vickers 1986: 71--81.

Mattusch, C.C. 1982. Bronzeworkers in the Athenian Agora. Princeton (NJ): American School of Classical Studies. Agora Picture Books 20.

Met, C.B., D.W.J. Gil., H.A. Forbes \& L. Foxhald. In press. Rural settlement change in the Methana peninsula, Greece, in G. Barker (ed.), Roman agrarian structure: archaeological survey in the Mediterranean. Rome.

Moon, W.G. 1979. Greek vase-painting in Midwestern collections. Chicago: The Art Institute of Chicago.

MoOREY, P.R.S. 1980. Metal wine-sets in the Ancient Near East, Iranica Antiqua 15: 181-97.

MORRIS, I. 1987. Burial and ancient society: the rise of the Greek city-state. Cambridge: Cambridge University Press.

OsboRne, R. 1985. Demos: the discovery of Classical Attika. Cambridge: Cambridge University Press.

1987. The viewing and obscuring of the Parthenon frieze, Journal of Hellenic Studies 107: 98-105. 
PARKER, A.J. 1984. Shipwrecks and ancient trade in the Mediterranean, Archaeological Review from Cambridge 3,2: 99-112.

PRITCheTT, W.K. 1956. The Attic Stelai II, Hesperia 25: $178-317$

RABY, J. \& M. Vickers. 1986. Puritanism and positivism, in Vickers 1986: 217-23.

REITLINGER, G. 1963. The economics of taste II. London: Barrie and Rockliff.

RICHTER, G.M.A. 1904-5. The distribution of Attic vases, Annual of the British School at Athens 11: 224-42.

Robertson, M. 1985. Beazley and Attic vase painting, in D.C. Kurtz (ed.), Beazley and Oxford: 19-30. Oxford: Oxford University Committee for Archaeology.

Forthcoming. Attic vase-painting: Beazley's work and its effect on the subject, in preparation.

SHAPIRO, H.A. 1981. Art, myth and culture: Greek vases from southern collections. New Orleans: New Orleans Museum of Art and Tulane University.

Shefton, B.B. 1971. Persian gold and Attic black glaze: Achaemenid influences on Attic pottery of the 5th and 4 th centuries BC, in IXth International Congress of Classical Archaeology, Damascus 11-20 October 1969: 109-11. Damascus.

SherratT, A.G. 1987. Review of B. Otto, Die verzierte Keramik der Sesklo- und Diminikultur Thessaliens (Mainz), Classical Review 37: 320-21.

SNODgrass, A.M. 1980. Archaic Greece: the age of experiment. London: Dent.

1985a. The new archaeology and the classical archaeologist, American Journal of Archaeology 89: $31-7$.

1985b. Greek archaeology and Greek history, Classical Antiquity 4,2: 193-207.

1987. An archaeology of Greece: the present state and future scope of a discipline. Berkeley (CA): University of California Press.

Starr, C.G. 1982. Economic and social conditions in the Greek world, in J. \& N.G.L. Hammond (ed.), Cambridge Ancient History (2nd edition) III,3: 417-41. Cambridge: Cambridge University Press.

STEWART, A.F. 1983. Stesichoros and the François vase, in W.G. Moon (ed.), Ancient Greek art and iconography: 53-74. Madison (WI): University of Wisconsin Press.

StRONG, D.E. 1964. A Greek silver head-vase, British Museum Quarterly 28: 95-102.

1966. Greek and Roman gold and silver plate. London: Methuen.

THOMPSON, H.A. \& R.E. WYCHERLFY. 1972. The Agora of Athens: the history, shape and uses of an ancient city center. Princeton (NJ): American School of Classical Studies at Athens. Athenian Agora 14.

Tompkins, J.F. (ed.) 1983. Wealth of the ancient world: the Nelson Bunker Hunt and William Herbert Hunt Collections, Fort Worth (TX): Kimbell Art Museum.

Trendall, A.D. 1982. Vase-painting in South Italy and Sicily, in M.E. Mayo, The art of South Italy: vases from Magna Graecia: 15-21. Richmond (VA): Virginia Museum.

Vermeule, C.C., III. 1977. Greek sculpture and Roman taste: the purpose and setting of Graeco-Roman art in Italy and the Greek Imperial East. Ann Arbor (MI): University of Michigan Press.

VICKERS, M. 1983. Les vases peints: image ou mirage?, in F. Lissarague \& F. Thelamon (ed.), Image et céramique grecque: actes du Colloque de Rouen 25-26 novembre 1982: 29-44. Rouen: University of Rouen.

1984. The influence of exotic materials on Attic white-ground pottery, in H.A.G. Brijder (ed.), Ancient Greek and related pottery: 88-97. Amsterdam: Allard Pierson Museum. Allard Pierson Series 5.

1985a. Artful crafts: the influence of metalwork on Athenian painted pottery, Journal of Hellenic Studies 105: 108-128.

1985b. Early Greek coinage, a reassessment, Numismatic Chronicle 145: 1-44.

1985c. Greek and Roman antiquities in the seventeenth century, in O. Impey \& A. MacGregor (ed.), The origins of museums: the cabinet of curiosities in sixteenth-and seventeenth-century Europe: 223-31. Oxford: Oxford University Press.

1985/6. Imaginary Etruscans: changing perceptions of Etruria since the fifteenth century, Hephaistos 7/8: 153-68.

1986a. Silver, copper and ceramics in ancient Athens, in Vickers 1986b: 137-51.

1986b. (ed.). Pots and pans: precious metal and ceramics in the Muslim, Chinese and GraecoRoman worlds. Oxford: Oxford University Press. Oxford studies in Islamic art 3.

1987. Value and simplicity: eighteenth-century taste and the study of Greek vases, Past and Present 116: 98-137.

VICKERS, M., O. IMPEY \& J. ALLAN. 1986. From silver to ceramic. Oxford: Ashmolean Museum.

WALTERS, H.B. 1905. History of ancient pottery. London: John Murray.

1921. Catalogue of the silver plate (Greek, Etruscan and Roman) in the British Museum. London: British Museum.

WOOLlEY, L. 1953. A forgotten kingdom. Harmondsworth: Penguin.

WyChERLEY, R.E. 1978. The stones of Athens. Princeton (NJ): Princeton University Press.

YounG, R.S. 1951. An industrial district of ancient Athens, Hesperia 20: 135-288. 